\title{
The coexistence of hemophagocytic syndrome and DRESS syndrome that develops in the course of sepsis in an elderly patient in intensive care unit
} Yoğun bakımda yatan yaşlı hastada sepsis seyrinde gelişen hemofagositik sendrom ve DRESS sendromu birlikteliği

\author{
Salih Tünbekici (D) Şükriye Miray Kılınçer Bozgül (D) Devrim Bozkurt (D) \\ Ege University Medical Faculty Hospital, Department of Internal Medicine, Izmir, Turkey
}

\begin{abstract}
Sepsis is one of the leading causes of mortality in intensive care units. Its mortality increases, especially with the high number of comorbidities and immunosuppression. Hemophagocytic syndrome is an uncontrolled cytokine storm that develops in the course of increased inflammatory conditions such as sepsis. The clinical picture is very wide; because of nonspecific symptoms. For this reason; to diagnose hemophagocytic syndrome, it must be kept in mind. Mortality in hemophagocytic syndrome is especially high in intensive care patients. Drug reaction with eosinophilia and systemic symptoms syndrome is a rare, infrequent drug reaction. The clinical picture is heterogeneous and symptoms may be prolonged despite discontinuation of the drug. Overlap of different diagnoses in elderly patients; In the presence of multiple drug use and chronic diseases, clinical management is difficult and early initiation of effective treatment can be delayed. In this case report; a 66-year-old male patient who underwent nephrostomy due to bilateral hydronephrosis and who developed sepsis and HPS in the follow-up after hospitalization with high fever and complicated with drug reaction with eosinophilia and systemic symptoms syndrome during treatment is presented.
\end{abstract}

Keywords: Sepsis, critical care, eosinophilia.

\section{ÖZ}

Sepsis, yoğun bakımda mortalitenin önde gelen sebeplerinden birisidir. Sepsis, komorbiditeler ile immünsupresyon varlığında mortaliteyi geriatrik hastalarda daha da artırmaktadır. Hemofagositik sendrom, sepsis gibi artmış inflamatuvar durumların seyrinde gelişen kontrolsüz sitokin fırtınasıdır. Klinik tablo heterojen olduğu için akla gelmedikçe tanı konulması zordur. Bu sendromun mortalitesinin özellikle yoğun bakım hastasında yüksek olduğu bilinmektedir. DRESS; çok nadir görülen fakat ağır seyredebilen ilaç reaksiyonudur. Klinik tablo heterojendir ve ilacın kesilmesine rağmen bulgular uzayabilir. Yaşlı hastalarda farklı tanıların örtüşmesi; çoklu ilaç kullanımı ve kronik hastalıkların da varlığında klinik yönetimi zorlaştırmakta ve etkin tedavinin erken başlanmasını geciktirmektedir. Bu olgu sunumunda; bilateral hidronefroz sebebi ile nefrostomi takılan ve ateş yüksekliği sebebiyle ile servise yatırıldıktan sonra izlemde sepsis, hemofagositik sendrom gelişen ve tedavi sırasında DRESS sendromu ile komplike olan 66 yaşında erkek hasta sunulmuştur.

Anahtar Sözcükler: Sepsis, yoğun bakım, eozinofili.

\section{INTRODUCTION}

Sepsis is defined in the current literature as a lifethreatening condition caused by an irregular host response to infection (1). Sepsis-related mortality reported as $35 \%$ in epidemiological studies (2), this rate reaches $60 \%$ in patients who develop septic shock. Despite all treatment options, sepsis is one of the leading causes of death in an intensive care patient. 
Hemophagocytic syndrome (HPS), on the other hand, is a rare but high-mortality clinical emergency that develops as a result of excessive activation of the inflammatory process (3).

Drug Reaction with Eosinophilia and Systemic Symptoms (DRESS) syndrome is a very rare serious drug reaction with systemic involvement (4). Geriatric diseases are often atypical and complex, causing some clinical conditions to overlap. This, in turn, causes us to encounter some difficulties in diagnosis and treatment, as in our case. In this case presentation, geriatric patient who was admitted to intensive care with a diagnosis of sepsis, complicated by HPS in follow-up and accompanied by DRESS syndrome, are discussed by literature data.

\section{Case presentation}

A 66-year-old male patient was interned for service monitoring due to a urinary tract infection. $\mathrm{He}$ had diagnosis of hypertension, diabetes mellitus, chronic kidney failure in his medical history. He had left nephrostomy due to bilateral hydronephrosis and was being treated with antibiotics containing meropenem, ertapenem, tigecycline due to the growth of carbapenemresistant Klebsiella Pneumonia. At the third week of treatment, after a change in conscious, fever, increase in liver function tests and bisitopenia; he was transferred to the Internal Medicine Intensive Care Unit with a preliminary diagnosis of sepsis. Glasgow Coma Scale was nine in admission. Patient's blood pressure was $130 / 70 \mathrm{mmHg}$, pulse $83 / \mathrm{min}$, respiratory rate $16 / \mathrm{min}$, fever $37.9^{\circ} \mathrm{C}$, fingertip saturation $94 \%$ in room air. AST 178 U / L, ALT 120 U / L, ALP 176 U / L, GGT 64 $\mathrm{U} / \mathrm{L}$, albumin $2.5 \mathrm{mg} / \mathrm{dL}$, urea $132 \mathrm{mg} / \mathrm{dL}$, creatinine $6.1 \mathrm{mg} / \mathrm{dL}$, CRP $41 \mathrm{mg} / \mathrm{L}$, ph 7.29, bicarbonate $13 \mathrm{mmol} / \mathrm{L}$, leukocyte $8750 / \mu \mathrm{L}$, hemoglobin $9.6 \mathrm{~g} / \mathrm{dL}$, platelets $50.000 / \mu \mathrm{L}$, INR 2, fibrinogen $271 \mathrm{mg} / \mathrm{dL}$ were in laboratory findings. No biliary tract pathology was detected in magnetic resonance cholangiography (MRCP), which was taken after intrahepatic biliary tract dilatation, $10.5 \mathrm{~mm}$ in the proximal section of the ductus choledocus. Bone marrow aspiration and biopsy was performed on the patient after serum triglyceride $188 \mathrm{mg} / \mathrm{dl}$, HDL cholesterol $5 \mathrm{mg} /$ $\mathrm{dL}$, ferritin $1087 \mu \mathrm{g} / \mathrm{L}$, which was considered with a preliminary diagnosis of HPS associated with sepsis due to deepening in cytopenia, increased consciousness disorder, continued fever and reported as normocellular bone marrow. $400 \mathrm{mg} / \mathrm{kg} /$ day; 5 days, intravenous immunoglobulin (IVIG) was added to treatment with sepsis-related HPS diagnosis in a patient with 5 / 8 criteria from HPS diagnostic criteria. On the fourth day of treatment, his cytopenia improved and bilirubin levels declined. But on the eighth day, widespread maculopapular rashes appeared throughout the body, the number of eosinophils was found to be $1000 / \mu \mathrm{L}$ on the hemogram, and again increase in the liver function tests and bilirubin progression were observed. $1 \mathrm{mg} / \mathrm{kg}$ prednisolone was added to the treatment with the diagnosis of DRESS syndrome. Viral hepatitis markers including hepatitis A, B, C and anti-nuclear antibody (ANA) test were negative. During follow-up, the patient's rash decreased, and there was an improvement in bilirubin and liver function tests. The patient, who was evaluated as end-stage renal failure, was enrolled in a routine hemodialysis program and on the fifteenth day, was transferred to the service.

\section{DISCUSSION}

Hemophagocytic syndrome should be the diagnosis that should come to mind in cases when clinical follow-up worsens and / or does not improve despite appropriate parenteral antibiotic use and hemodynamic management in a sepsis patient. (5). In adults, malignancy, infection, autoimmune and autoinflammatory diseases are the leading causes of HPS (3). Hemophagocytic syndrome occurs as a clinical condition in which many organ systems are affected and have nonspecific symptoms and findings such as fever, cytopenia, coagulopathy, hepatosplenomegaly, change of consciousness, seizure and hemodynamic decompensation (3). 2004 diagnostic criteria include fever, cytopenia in at least 2 peripheral blood serial, splenomegaly, hypertriglyceridemia and / or hipofibrinojemia, increased serum ferritin level, low natural killer cell activity, increased serum soluble interleukin-2 (sIL-2R) levels, hemophagocytosis in bone marrow or other tissues. The presence of at least 5 of these criteria is required for diagnosis (6). Our case is a geriatric patient with a high frequency of comorbid disease with nephrostomy and recurrent infections in the urine taken from nephrostomy. During service monitoring, he was consulted with a change of consciousness, fever height, low fibrinogen, and was admitted to the Internal Medicine Intensive Care Unit. Hemophagocytic syndrome was considered in the current clinical picture and was diagnosed with 5 / 8 criteria as a result of laboratory examinations. 
Table-1. DRESS Syndrome; RegiSCAR scoring.

\begin{tabular}{llll}
\hline & NO & YES & UNKNOWN \\
\hline Fever $\left(\geq 38.5^{\circ} \mathrm{C}\right)$ & -1 & 0 & -1 \\
Enlarged lymph nodes $(\geq 2,>1 \mathrm{~cm})$ & 0 & 1 & 0 \\
Atypical lymphocytes & 0 & 1 & 0 \\
Eosinophils & & 1 & \\
$\quad 700-1499$ or $10-19 \%$ & & 2 & 0 \\
$\quad \geq 1500$ or $\geq 20 \%$ & 0 & & 0 \\
$\quad$ Extend $50 \%$ & 0 & 1 & 0 \\
Skin rash $\quad-1$ & 1 & 0 \\
At least 2 of; edema, infiltration, purpura, scaling & -1 & 0 & \\
Biopsy suggesting DRESS & & & -1 \\
Internal organ involvement $\quad$ one & & 1 & 0 \\
\hline Resolution $>15$ days & -1 & 2 & 0 \\
Research done to exclude alternative diagnoses & 0 & 1 & \\
\hline
\end{tabular}

Final score: $<2$ =no case, $2-3=$ possible case, $4-5$ =probable case, $>5=$ definitive case

* 1 point if 3 of the following tests are performed and are negative: HAV, HBV, HCV, mycoplasma, chlamydia, ANA, blood culture.

Current treatment was updated as antibiotic revision and IVIG. Good response to treatment was provided. DRESS syndrome was considered rather than sepsis and HPS progression in the patient, who was not clinically impaired despite the development of skin rash, eosinophilia and increase in liver function tests. The drug that most often causes DRESS syndrome is carbamazepine, and antibiotics are also in etiology (4). RegiSCAR scoring system was used for diagnostic criteria (7) (Table-1) and 1 point with skin rash, 1 point with internal organ involvement, 1 point with eosinophils, 1 point with excluding alternative diagnosis were evaluated as a probable case with 4 points. As fist line treatment, steroid $1 \mathrm{mg} / \mathrm{kg}$ was added, and the patient's clinical and laboratory findings improved.

\section{CONCLUSION}

As a result, HPS can often occur with sepsis / sepsis-like clinic or be seen during sepsis. Multiple organ failure and mortality are inevitable if rapid diagnosis and treatment are not started. diagnosis cannot be made unless it comes to mind. Laboratory tests including ferritin, triglycerides, HDL-cholesterol, fibrinogen, and bone marrow aspiration will be guiding with the presence of long-term fever and cytopenia. If DRESS syndrome comes to mind in patients with long-term drug use, both the patient's treatment process will accelerate, and it will be a notification for possible discontinuation of the drug. Geriatric patients, in particular, should be evaluated multidisciplinary both in terms of concomitant comorbidities and overlapping clinical diagnoses due to multiple drug uses.

\section{Conflict of Interest}

The authors did not declare a conflict of interest. 


\section{References}

1. Shankar-Hari M, Phillips GS, Levy ML, et al. Developing a New Definition and Assessing New Clinical Criteria for Septic Shock: For the Third International Consensus Definitions for Sepsis and Septic Shock (Sepsis-3). Jama 2016; 315 (8): 775-87.

2. Kim HI, Park S. Sepsis: Early Recognition and Optimized Treatment. Tuberc Respir Dis (Seoul) 2019; 82 (1): 6-14.

3. Lachmann G, La Rosée P, Schenk T, Brunkhorst FM, Spies C. Hemophagocytic lymphohistiocytosis: A diagnostic challenge on the ICU. Anaesthesist 2016; 65 (10): 776-86.

4. Walsh SA, Creamer D. Drug reaction with eosinophilia and systemic symptoms (DRESS): a clinical update and review of current thinking. Clin Exp Dermatol 2011; 36 (1): 6-11.

5. Bozkurt D. İ̧̧ Hastalıklarında İmmün Sistem İlişkili Aciller. 1 Baskı. Ankara: Palme Yayınevi; 2020: 69-80.

6. Henter JI, Horne A, Aricó M, et al. HLH-2004: Diagnostic and therapeutic guidelines for hemophagocytic lymphohistiocytosis. Pediatr Blood Cancer 2007; 48 (2): 124-31.

7. Kardaun SH, Sekula P, Valeyrie-Allanore L, et al. Drug reaction with eosinophilia and systemic symptoms (DRESS): an original multisystem adverse drug reaction. Results from the prospective RegiSCAR study. $\mathrm{Br} \mathrm{J}$ Dermatol 2013; 169 (5): 1071-80. 